\title{
КАК РОЖДАЛСЯ «СОВЕТСКИЙ ПАТРИАРХАТ». ГРИГОРИЙ БАТКИС О СЕКСУАЛЬНОЙ РЕВОЛЮЦИИ В РОССИИ
}

\section{ОЛЬГА ЗДРАВОМЫСЛОВА}

\begin{abstract}
В статье анализируется брошюра одного из основоположников российской соичильной гигиены $и$ санитарной статистики Г.А. Баткиса «Сексуальная революичия в России», изданная в 1925 г. 8 Германии и никогда не публиковавшаяся в России [Batkis 1925]. Брошюра Баткиса - подлинный документ эпохи 1917-1923 г2., имеющей первостепенное значение для понимания советского гендерного проекта, а также новый исторический источник, дополняющий представления об истоках и обстоятельствах возникновения советского этатистского гендерного порядка или «советского патриархата».
\end{abstract}

Концепция сексуальной револючии у Баткиса существенно отличается от современных представлений. Сексуальная револючия выступает здесь непосредственным результатом, прямым продолжением Октябрьской революции: она направлена на разрушение «старого русского семейного и брачного порядка» как сочиально несправедливого и исторически обреченного.

Баткис объединяет элементы трех соииальных революиий, которые современные исследователи обычно разделяют: сексуальной, гендерной и семейной. Однако их движущей силой являются у него не прогресс индивидуализачии и расширение пространства индивидуальной свободы, а воля власти, выраженная в «законодательстве русской коммунистической револючии» [Batkis 1925]. Фактически сексуальная революичи у Баткиса совпадает с принятием первых большевистских законов о семье и браке.

В статье рассматривается сходство и различие интерпретаций сексуальной револющии в России у Григория Баткиса и Вильгельма Райха. Сексуальная революичия в России не привела к настоящим изменениям сексуальной и гендерной культуры, но было бы неверно считать ее проигравщей, скорее ее можно назвать отложенной.

Ключевые слова: сексуальная революиия, советский патриархат, советский гендерньй проект.

Рукопись одного из основоположников российской социальной гигиены и санитарной статистики Григория Абрамовича Баткиса (1895-1960) «Сексуальная революция в России», переведенная на немецкий язык, была опубликована в виде брошюры в 1925 г. в Германии [Batkis 1925].

Тема сексуальной революции не была случайной в научной биографии Г.А. Баткиса. Он с юности занимался социальными проблемами медицины, т.е. вопросами, возникавшими на стыке медицины, демографии, социологии и статистики, поэтому не мог обойти вниманием радикальные изменения, которые происходили после Октябрьской революции в сексуальном поведении населения, прежде всего молодежи.

ОЛЬГА МИХАЙЛОВНА ЗДРАВОМЫСЛОВА (olgazdrav@gorby.ru), МЕЖДУНАРОДНЫЙ ФОНД СОЦИАЛЬНОЭКОНОМИЧЕСКИХ И ПОЛИТОЛОГИЧЕСКИХ ИССЛЕДОВАНИЙ, РОССИЯ.

СТАТЬЯ ПОСТУПИЛА В РЕДАКЦИЮ В ОКТЯБРЕ 2016 Г. 
Баткис принадлежал к тем российским интеллигентам, кто принял Октябрьскую революцию и кто с энтузиазмом начал работать на Советскую власть. Являясь ее убежденным сторонником, Баткис пишет в 1923 г. небольшой по объему текст (23 страницы), в котором он излагает основные принципы большевистской идеологии и политики в сфере гендерных отношений, семьи и сексуальности. Однако ни в СССР, ни в постсоветской России эта работа не издавалась, она не входила в списки трудов ученого и не упоминается в его опубликованных биографиях.

В Большой медицинской энциклопедии о Г.А. Баткисе говорится как об организаторе советского здравоохранения, специалисте по социальной гигиене и санитарной статистике, авторе 150 научных работ, посвященных этим вопросам [Большая медицинская... 1988]. Г.А. Баткис известен также как автор первого советского учебника по социальной гигиене (1936 г.), который много раз переиздавался и «сыграл большую положительную роль в подготовке врачей» в СССР [Социальная гигиена... 1984: 21].

Профессионализм ученого и педагога сочетался в Баткисе с темпераментом пропагандиста, искренне разделявшего в 20-е годы большевистские идеи. Будучи еще студентом медицинского факультета Киевского университета, Баткис стал членом Киевского городского Совета рабочих, крестьянских и солдатских депутатов и губернским комиссаром здравоохранения. Сразу после революции большевики издают многочисленные декреты по вопросам охраны здоровья населения ${ }^{1}$ и создают административные органы по управлению здравоохранением. Поэтому уже в 1919 г., после окончания университета, Баткис, вступивший в большевистскую партию, был направлен в Киевский губернский комиссариат здравоохранения и вскоре стал его председателем. В 1923 г. он переехал в Москву и приступил к работе на кафедре социальной гигиены во 2-ом Медицинском институте, затем в 1-ом Медицинском институте [Карлсен 2005]. С этого времени начинается его деятельность исследователя, теоретика, педагога и просветителя.

На брошюру Баткиса «Сексуальная революция в России» ссылался Вильгельм Райх - выдающийся психоаналитик и социолог, ученик и оппонент Зигмунда Фрейда [Райх 1997: 221, 240-241]. Соединив и переосмыслив идеи Маркса и Фрейда, Райх создал концепцию «сексуальной революции», основанную на принципах «сексуально-экономического регулирования», которое, как он доказывал, заменит традиционное нормативное принудительное регулирование половой жизни или «сексуальное угнетение» [Райх 1997: 22-30].

Судя по тексту второй части («Борьба за «новую жизнь» в СССР») знаменитой книги Вильгельма Райха «Сексуальная революция», брошюра Григория Баткиса оказалась для Райха одним из важных источников. Немаловажно и то, что Баткис и Райх были современниками, людьми одного поколения, близких социально-политических взглядов. Хотя они смотрели на события в России из разных стран, описывали их с разной степенью подробности, использовали разные подходы - преимущественно теоретический (Райх),

1 В первые годы Советской власти В. И. Лениным были подписаны около 100 декретов по различным вопросам охраны здоровья трудящихся и медицинской науки [Социальная гигиена... 1984: 27 ]. 
преимущественно идеологический и практический (Баткис), - их оценки происходившего в России переворота перекликаются и во многом совпадают.

Нельзя также не отметить, что понятие «сексуальная революция» было употреблено Баткисом в 1925 г., а первое издание книги Райха вышло в 1930 г. Таким образом, Григория Баткиса можно считать соавтором термина, введение которого в науку и общественную дискуссию связывается с именем Вильгельма Райха. Однако сама брошюра, изданная в Германии и внимательно прочитанная Райхом, на долгие годы выпала из отечественной науки и общественной дискуссии.

Сегодня, через сто лет после Русской революции 1917 г., большевистское наследие в сфере гендерной идеологии и политики вновь становится вызовом как для российской власти, так и для общества. Это непосредственно связано с идеологией защиты традиционных ценностей, доминирующей в официальной риторике и СМИ. Важным пунктом этой идеологии «консервативного поворота», начавшегося в России во второй половине 2000-ых годов, является полное неприятие Русской революции 1917 г., в том числе, «социальных экспериментов 1917-1920 годов», которые рассматриваются как сознательное разрушение семьи - «одного из оплотов самодержавия» и «связей между браком, религией и церковью» через узаконивание «фактического» брака [Концепция государственной...2014].

В этом контексте забытая работа Баткиса о сексуальной революции в России важна не только для восстановления полноты научного наследия крупного отечественного ученого. Это брошюра - подлинный документ эпохи 1917-1923 гг., имеющей первостепенное значение для понимания советского гендерного проекта - воспроизводит логику тех, кто связывал с большевистской революцией прорыв к новому обществу. В нем не экономические обстоятельства или любая другая форма принуждения, а только взаимное чувство скрепляет союз двух свободных и равных людей. Трудно переоценить значимость этой идеи для понимания фундаментальных сдвигов, которые происходили на протяжении всего XX века в институте семьи и сфере интимности [Giddens 1992; Вишневский 2010: 129 $-149]$.

В то же время брошюра Баткиса - новый исторический источник, дополняющий представления об истоках и обстоятельствах возникновения советского этатистского гендерного порядка [Здравомыслова, Темкина 2004] или «советского патриархата». В свой классический период (1930-е - середина 1950-х годов) он являлся одной из «несущих конструкций» тоталитарной политики, которая полностью подчиняла человека государству, распространяя контроль власти на частную сферу и личную жизнь граждан.

\section{СЕКСУАЛЬНАЯ РЕВОЛЮЦИЯ В РОССИИ: ДУХ ЗАКОНОВ}

Одна из трудностей современного восприятия текста Баткиса состоит в том, что он написан стилем, свойственном деятелям той эпохи: утопизм соединяется здесь с волевым импульсом к преобразованию реальности. Патетический слог в тех частях текста, где, по выражению Райха, «предвосхищается желаемое конечное состояние», чередуется с описанием конкретных положений семейно-брачного законодательства и практических мер 
советской власти в сферах защиты материнства и детства, здравоохранения и борьбы с проституцией.

Другая трудность состоит в том, что концепция сексуальной революции, которую развивает Баткис, существенно отличается от современных представлений о ней как длительном, «глубинном дискурсивном процессе отделения сексуальности от репродукции», историческими предпосылками которого являются индивидуализация, ослабление внешнего контроля за сексуальным поведением и появление эффективной контрацепции [Кон 2010]. Концепция Баткиса проще: она лишена теоретической глубины, благодаря чему ее можно объяснить самому неподготовленному читателю, и в этом состояла, очевидно, одна из целей написания брошюры.

Для Баткиса сексуальная революция - отражение Октябрьской и ее непосредственный результат. Она имеет ясную, исторически прогрессивную цель: сексуальная революция направлена против «системы угнетения», которую олицетворял «старый русский брачный и семейный порядок», и против его законов, утверждавших «безграничный деспотизм, произвол, насилие $u$ порабощение женщин $u$ детей», находившихся под неограниченной властью мужа и отца. Краткий обзор прежнего, царского семейного законодательства служит для Баткиса лишь неопровержимым доказательством исторической правоты сексуальной революции, разрушившей до основания эти «средневековые нормы». Баткис противопоставляет этим нормам «советские законы в отношении сексуальной сферыл,, которые, утверждает он, «отвечают требованиям преобладающей части населения» и согласованы «с достижениями современной науки», «законами развития», в том числе «законом развития свободных отношений». Устраняя частную собственность и «понятие собственности в сексуальной cфере», эти законы подрывают не только власть главы семьи, но положение семьи как экономического института и ее автономию. В результате «семья не является больше источником накопления имущества, которое наследуется от поколения к поколению»; семья перестает быть «личным делом каждого», «то, что раньше было личным делом, обязанностью, например, воспитание детей, становится общественным делом».

Следствием этого стали процессы, определившие противоречивое начало советского гендерного проекта. Современные исследователи характеризуют их как дефамилизацию (ослабление семейных связей) и политическую мобилизацию женщин [Айвазова 1998; Здравомыслова, Темкина 2004: 304 - 310; Пушкарева 2012]. Баткис формулирует это языком своего времени: «политически освобожденная женщина вольется в открытый процесс производства и изменит старые установки, в соответствии с которыми она прежде была подчинена детям, кухне и иеркви» или скована национальными обычаями, закреплявшими ее бесправное положение и мешавшими ее «полному освобождению».

Описывая стратегические цели и задачи сексуальной революции, Баткис не признает ни утопичности большевистского проекта, ни опасности революционных методов его 
осуществления ${ }^{2}$ " «Светское законодательство проложило новый, до этого непроторенный путь...Раньще мир не знал ни одного общества, ни одной революции, которые ставили такие ичели и задачи», - заявляет он, в точности следуя тому, по выражению Ханны Арендт, «современному пониманию революции», которое с необходимостью включает «представление об открываемом ею новом этапе истории». [Арендт 2011: 30].

Баткис объединяет элементы трех социальных революций, которые современные исследователи обычно разделяют: сексуальной, гендерной и семейной [Кон 2010]. Однако их движущей силой выступают у него не индивидуализация и расширение пространства индивидуальной свободы, а воля власти, выраженная в «законодательстве русской коммунистической револючии». Его сила и действенность - в разрыве с традициями: оно не основано «на теории, отделенной от реальности», подобно законодательству «первой франиузской револючиии», и «не касается вечных проблем, как Десять Заповедей Моисея». Иначе говоря, новые законы не опираются ни на умозрительные принципы, ни на религиозную мораль. Они «сообразуются только с действительностью и наукой $u$ отказываются от изошренного лицемерия буржуазного законодательства ${ }^{3}$.

Сексуальная революция в таком ее понимании совпадает с принятием первых большевистских законов, важнейшие из которых - декреты "О гражданском браке, детях и о введении книг актов гражданского состояния (1917 г), "О разводе» (2017 г.) и первый советский семейный кодекс - Кодекс законов об актах гражданского состояния, брачном, семейном и опекунском праве РСФСР (1918 г.).

Значительную часть брошюры занимает изложение этого Кодекса, в первую очередь, тех его положений, которые подрывали религиозные основания института брака, закрепленные прежними царскими законами. В противоположность им новые законы установили «только гражданский (светский) брак», заключаемый в загсе ${ }^{4}$. Они уравняли

\footnotetext{
${ }^{2}$ Н.А. Бердяев предупреждал в 1924 г., что «утопии оказались гораздо более осуществимыми, чем казалось раньше. И теперь стоит другой вопрос, как избежать их окончательного осуществления..., как вернуться к неутопическому обществу, к менее совершенному...» [Бердяев 1924: 121-122].

${ }^{3}$ Нетрудно заметить, что Баткис перефразировал здесь идеи, высказанные В.И. Лениным, хотя не цитировал его прямо: «Именно большевистская револючия является единственной последовательно демократической революиией в отношении к таким вопросам, как брак, развод и положение внебрачных детей. А это вопрос, затрагивающий самым непосредственным образом интересы большей половины населения в любой стране. Только большевистская революиия впервые, несмотря на громадное число предшествовавших ей и называющих себя демократическими буржуазных революиий, провела решительную борьбу в указанном отношении, как против реакцичонности и крепостничества, так и против обычного лицемерия правящих и имущих классов ... Современная буржуазная демократия, даже во всех наиболее демократических буржуазных республиках, проявляет себя в указанном отношении именно крепостнически по отношению к женщине и по отношению к внебрачным детям.... Россия ... отличается от других стран только тем, что ее законы не освящают лищемерия и бесправного положения женщины и ее ребенка, а открыто и от имени государственной власти объявляют систематическую войну против всякого лицемерия и всякого бесправия» [Ленин 1970: 31-33].
}

${ }^{4}$ Первый российский кодекс - КЗАГС (Кодекс законов об актах гражданского состояния, брачном, семейном и опекунском праве РСФСР) 1918 г. определял: «Только гражданский (светский) брак, зарегистрированный в 
зарегистрированный и фактический брак: «в любых отношениях, которые носят характер брака, партнеры обладают те ми же правами и обязанностями, как если бы они официально зарегистрировались». Сделав брак и его расторжение исключительно частным делом, законодательство невероятно упростило процедуру развода ${ }^{5}$.

Новый кодекс ввел принцип равенства не только в личных и имущественных отношениях супругов, но и в родительских ролях: «воспитание происходит сообща, $u$ никто из родителей не может действовать в этом произвольно и без согласия другого».

Если прежние законы лишали прав и защиты внебрачных детей, то советское законодательство уравняло в правах внебрачных детей и, последовательно выступая против любых проявлений патриархальной семейной власти, провозгласило, что «основная иеель семейного права состоит в защите интересов и прав детей». Поэтому, например, в спорных случаях судебные решения всегда определялись интересами ребенка, а не родителей.

Баткис обвиняет прежние царские законы в том, что, бесцеремонно вмешиваясь в интимные отношения людей (например, устанавливая уголовное наказание за аборт), они маскировали лицемерие общественной морали, строго контролировавшей сексуальную сферу, одновременно поощряя проституцию и закрывая глаза на насилие в отношении женщин и детей. Поэтому он особо останавливается на том, что по новому советскому законодательству уголовное наказание, предполагающее лишение свободы, вводилось «за сексуальные действия с детьми»; «за принуждение женщины к сексуальному контакту посредством физической силь или психического влияния, используя ее беспомощное состояние или зависимость, материальную или служебную».

Новое законодательство, подчеркивает Баткис, установило, что борьба с «многовековым пережитком всего мира» - проституцией - «направлена против тех, кто является посредниками или сообщниками в организации проституции», и против тех, «кто жестоко, насильственно, грубо и эгоистично ведет себя в сексуальной жизни, нарушает интересы и подавляет достоинство другого человека» ${ }^{6}$.

органе записей актов гражданского состояния, порождает права и обязанности супругов, изложенные в настоящем разделе. Брак, совершенный по религиозным обрядам и при содействии духовных лиц, не порождает никаких прав и обязанностей для лиц, в него вступивших, если он не зарегистрирован установленным порядком» - КЗАГС. Статья №818. URL: http://istmat.info/node/31624 (дата обращения 04.02.2017).

5 «Основанием для развода может служить как обоюдное согласие обоих супругов, так и желание одного из них развестись. Просьба о расторжении брака может быть приносима как в письменной, так и в устной форме с занесениям ее в протокол». КЗАГС. Статья №818. URL: http://istmat.info/node/31624 (дата обращения 04.02.2017).

${ }^{6}$ Речь идет о положениях Уголовного кодекса РСФСР (1922 г.), согласно которым налагалась уголовная ответственность за «принуждение из корыстных или иных личных видов к занятию проституцией, совершенное посредством физического или психического воздействия» и «сводничество, содержание притонов разврата, а также вербовка женщин для проституции», в особенности «если же вовлеченные в проституцию состояли на попечении или в подчинении обвиняемого или не достигли совершеннолетия, то 
«Однако законодательство никогда не вмешивается в сексуальные отношения людей до тех пор, пока связь происходит между двумя взрослыми людьми без какого-либо принуждения». Этим обосновывалось то, что в Уголовном кодексе РСФСР (1922 г.) в отличие от Уголовного Уложения царской России не было статьи, преследовавшей за гомосексуализм.

Баткис, как и Райх признавал определяющую роль, которую играет сексуальное угнетение в том, что «естественные силы в человеке» подавлены. Оба доказывали это, приводя пример законов царской России, охранявших устои патриархальной семьи, в которой, утверждал Райх, «происходит воспроизводство структур авторитарного государства» и увековечение сексуального угнетения [Райх 1997: 185]. Поэтому он признавал, что «самым четким выражением первого натиска сексуальной революции на систему традиционной сексуальности было советское право, регламентировавшее новые сексуальные отношения» [Райх 1997: 180]. Баткис, в отличие от Райха, считал, что патриархальный семейный и брачный порядок уже уничтожен: «в течение не особо длительного периода существования советской системы стало возможным не только понять, но и искоренить все пошлые гадкие и продолжительные по времени признаки подавления женщины». Он стремится доказать, что «новый порядок» уже благотворно воздействует на сексуальное поведение молодежи.

\section{О ВЛИЯНИИ СЕКСУАЛЬНОЙ РЕВОЛЮЦИИ НА «МОЛОДОЕ ОБЩЕСТВО»}

Баткис решительно опровергает «противников молодого общества», которые придумали миф о дикой свободной любви, о сочиализачии женщины и «подобной чепухе, а также распространили её по всему миру... Как глупь и пошль эти сенсачионные новости! Наблюдение за повседневной жизнью учит нас тому, что происходит нечто прямо противоположное».

В этом заявлении можно заметить полемику с Питиримом Сорокиным: замечание последнего о разрушении института брака и деградации сексуальной морали в Советской России было широко известным из-за резкой критики его В.И. Лениным [Ленин 1970: 32].

Сорокин так же, как Баткис, считал, что сексуальная революция - не менее значительное явление, чем революция политическая, утверждая, что она «так же важна, как самые драматические политические или экономические перевороты» [Сорокин 2006:19]. В 1922 г. в статье, опубликованной в журнале «Экономист», основываясь на статистике разводов, Питирим Сорокин делал вывод: «На 10000 браков в Петрограде теперь приходится 92,2 развода - цифра фантастическая, причем из 100 расторгнутых браков 51,1 были продолжительностью менее одного года, $11 \%$ - менее одного месяца, $22 \%$ - менее двух месяцев, 41\% - менее 3-6 месяцев и лишь 26\% - свыше 6 месяцев. Эти цифры говорят, что современный легальный брак - форма, скрывающая по существу внебрачные

наказание повышается на срок не ниже пяти лет лишения свободы». URL: https://ru.wikisource.org/wiki/Уголовный_кодекс_РСФСР (дата обращения 04.02.2017). 
половые отношения и дающая возможность любителям “клубники” “законно” удовлетворять свои аппетиты» [Сорокин 1922: 83]. Хотя цифра разводов, которую приводит Сорокин, не кажется сейчас «фантастической», он точно указал на прогрессирующий кризис института брака, который делал все более заметным отделение сексуальности от брака и репродукции. Тем самым Сорокин, как и Баткис, фиксировал заметные изменения норм сексуального поведения, хотя оценивал их с противоположных позиций.

О том же самом свидетельствовали опросы, проведенные в самом начале 1920 -х годов. Интерпретируя их данные, С.И. Голод делает два важных вывода. Во-первых, мужские и женские модели сексуального поведения сблизились, что породило противоречивые следствия. С одной стороны, расширялась свобода сексуального выбора для обоих полов, и происходил переход к единой сексуальной морали. С другой стороны, женщины усваивали традиционные «мужские» стандарты, что, в свою очередь, препятствовало становлению новых отношений и способствовало закреплению традиционных (патриархатных) норм сексуального поведения [Голод 2005: 38-43].

Во-вторых, «проституция как социальное явление постепенно шла на спад» 7 , поскольку круг партнеров у женщин расширился за счет женихов и сожителей, тогда как контакты мужчин с проститутками сократились. Голод проводит аналогию с явлением, описанным Бертраном Расселом в отношении Англии периода распада викторианской морали: проституция утратила свое значение и стала менее распространенной, когда сделались возможными внебрачные сексуальные отношения молодого человека с девушкой своего круга. Вследствие этого возросло значение эмоциональных отношений самоценных и лишенных зависимости [Голод 2005: 52]. В Советской России в 1920-е годы появились признаки усиления аналогичной тенденции.

Современные интерпретации результатов исследований, проводившихся в 1922 1926 гг. среди молодежи, показывают, что Баткис опирался на реальные данные, когда говорил о развитии в молодежной, студенческой среде эмоциональных отношений, свободных от зависимости и принуждения. При этом он существенно преувеличивал эту тенденцию, объявляя ее чуть ли не доминирующей и игнорируя другие, более значимые, связанные как с устойчивостью традиционных моделей, так и с распадом ценностнонормативной регуляции сексуального поведения, вызванным влиянием войны и революции. Новые советские законы о браке и семье «накладывались» на эти деструктивные процессы, делая их особенно заметными.

Пытаясь понять сексуальную революцию 1920-х годов, современные исследователи избегают крайних оценок, но они согласны в том, что происходил процесс разрушения

\footnotetext{
${ }^{7}$ Если до Первой мировой войны и Февральской революции почти 48\% молодых горожан начали сексуальную жизнь с проститутками, то в 1914-1917 гг. — 32,0\%, в 1918-1920 гг. - 16,0\%, а в 1921-1923 гг. — менее 4\%. Если до революции услугами проституток пользовались $51 \%$ опрошенных мужчин, то после революции 8\% [Голосенко, Голод 1998: 62].
} 
традиционных моделей сексуального поведения, а новые, модернизированные нормы не успевали возникнуть и закрепиться [Fitzpatrick 1978: 271; Голод 2005: 41]. Тем не менее результаты опросов убедительно опровергали распространенные представления о «невообразимой вакханалии» [Голод 2005: 42] и подтверждают слова Баткиса, что «сексуальная револючия в России» не была разгулом «дикой свободной любви».

Хотя данные опросов не показывали, что среди молодежи возникли ясные ориентиры на свободные, самоценные и равноправные эмоциональные отношения [Голод 2005: 42], они, тем не менее, свидетельствовали, что эта тенденция, выражавшая, как доказывал Баткис, революционный дух первых советских законов, реально существовала. Разумеется, она не была только лишь результатом воздействия революционных законов, а выражала долговременные, глубинные процессы эмансипации сексуальности и «трансформации интимности» [Giddens 1992]. Эта тенденция остается ключевой для понимания сексуальности, которая «вписывается в необходимость создавать новую культурную жизнь под видом сексуального выбора» и тем самым «участвует в нашей свободе» [Фуко 1982].

Анализируя опыт послереволюционной России, Вильгельм Райх особо выделил то обстоятельство, что революционное законодательство «лишь обеспечило внешние (курсив В.Райха) условия процесса, который еще только должен был развернуться. Таким способом ему была придана определенная идеологическая форма. Недвусмысленное провозглашение отмены патриархальной власти посредством революционного закона разумелось само собой» [Райх 1997: 183].

Баткис подошел к аналогичному выводу: революционный переворот в семейнобрачном законодательстве, фактически отождествленный им с сексуальной революцией, создал предпосылки движения к новым отношениям, основанным на «идеальной связи двух свободных людей», — цели сексуальной революции, как он сам ее формулировал. Поэтому он обращался к молодежным сексуальным практикам, в которых видел подтверждение тому, что дух законов меняет жизнь и чувства людей, но «освобождение от сексуального угнетения» должно стать задачей будущей культурной революции. Выступая защитником «молодого общества» от его критиков и врагов, Баткис говорил о необходимости культурной работы, т.е. о половом просвещении и сексуальном воспитании, необходимых для создания и закрепления «новых обычаев новой жизни».

\section{ОТ РЕВОЛЮЦИОННЫХ ЗАКОНОВ К «СОВЕТСКОМУ ПАТРИАРХАТУ»}

Райх, как и Баткис, связывал решение вопроса о продолжении сексуальной революции с культурным развитием общества, предупреждая, что «культурная революция поставила гораздо более трудные вопросы, чем социальная» [Райх 1997: 189]. Он настойчиво подчеркивал, что торможение движения к свободе, которое его беспокоило в первую очередь, связано с тем, «как будут развиваться реальные противоречия между законами, гарантировавшими личную свободу, и реальностью семейных отношений, в быту, на производстве, общественной жизни, в целом» [Райх 1997: 190]. 
Проблему, которую Райх называл торможением сексуальной революции, понимал и Баткис. Он довольно откровенно писал, что в Советской России «положение $c$ производством таково, что женщины далеко не всегда имеют возможность работать на фабриках и в других учреждениях». Хотя по закону "семья не является больше источником накопления имущества, которое наследуется от поколения к поколению», она продолжает оставаться важным социальным институтом. Его главной функцией становится взаимная поддержка членов семьи, которая обеспечивает их выживание в бедственных материальных условиях. И хотя «регистрация брака не дает особых привилегий», она тоже является необходимой «уступкой жизни»: «Институт семьи ещуе имеет силу и практическое значение, и низкий уровень техники не позволяет немедленно обобществить образ жизни. Общественное воспитание детей может в силу недостатка материальных средств осуществиться только постепенно и через длительное время, и семья не может в одночасье освободиться от своих обязанностей перед детьми».

Когда Баткис переходит от прославления достижений сексуальной революции к реальным проблемам семьи и положения женщины, становится очевидным, что он отдавал себе отчет в существовании разрыва между революционными лозунгами и действительностью. Он не мог не видеть, что, разрушая патриархальную семью и провозгласив новую политику в отношении женщин, советская власть столкнулась с огромными трудностями, и их устранение не станет делом близкого будущего. Чтобы сгладить очевидное противоречие между идеологией и реальностью, Баткис определял советское право как «право переходного периода», когда «изменяется материальная жизнь, будь то необходимость наладить обеспечение граждан или воспитание детей».

Основным направлением гендерной политики советской власти становятся меры, учреждающие новые отношения женщины с государством, которое провозгласило политическое и экономическое равенство полов, но гарантировало женщине, прежде всего, защиту ее «основного права» — «права на материнство».

Баткис специально оговаривает, что «под особой защитой закона стоит мать... государство и общество провозглашаются опекуном и защитником детей и обеспечивают охрану женщин и детей во всех областях». В соответствии с этим Трудовой кодекс обеспечивает женщине возможность сочетать материнство и работу: продолжительный (на срок три месяца) материнский отпуск до и после рождения ребенка; специальный отпуск, предоставляемый кормящим женщинам, продолжающим работать; сокращение рабочего времени для работающих матерей.

Баткис перечисляет различные государственные меры, направленные на улучшение здоровья матери и ребенка и его поддержание. В случае развода «право матери на алименты предписывается в судебном порядке и по всей строгости». Словом, заключает Баткис, «право на материнство подтверждается действиями огромного количества учреждений, заключающимися в предоставлении матери и ребенку помощи и оказании заботыл».

Вместе с тем положение женщины-матери становилось все более трудным. Анализируя семейный Кодекс 1918 г., французский социолог права Шанталь КурильскиОжвэн замечает, что «теория... предусматривала передачу обществу семейных функций по 
воспитанию и содержанию детей. И правовые положения в определенной мере следовали ей. Считалось, что родительские права и обязанности сводятся к обязанностям, выполняемым под строгим контролем общества. Но на самом деле эти обязанности из-за роста числа разводов все более перекладывались на плечи женщин» [Курильски-Ожвэн 1995: 163].

«Семью нельзя «отменить»: ее надо заменить», — заметил Л.Д. Троцкий, имея в виду организацию «законченной системы общественного ухода и обслуживания», освобождающей женщину от хозяйственных функций, которые поглощают все ее силы [Троцкий 1991: 86]. Не справившись с этой задачей, но «отменив» революционными законами патриархальную семью, советское государство само становилось «отцовской властью» [Kukhterin 2000: 71], опекающей и контролирующей работающую мать.

Именно в этом контексте возникает «поразительный для того времени закон» [Здравомыслова 2010], «предоставляющий женщинам возможности при необходимости совершать аборты, делать их безопасно и гигиенично» [Batkis 1925]. Как и современные исследователи, Баткис справедливо видит в легализации медицинского аборта одну из самых значительных мер, осуществленных советской властью [Здравомыслова 2010; Сакевич и др. 2016]. Вместе с тем, в отличие от революционного брачно-семейного законодательства, которое, утверждает Баткис, опирается на передовую науку и соответствует прогрессивным тенденциям будущего, «вопрос о полезности аборта» неоднозначен. Он проистекает не из требований свободы, а из условий жизни, «принуждающих тысячи женщин к абортам». Принятие этого закона Баткис связывает исключительно с заботой о здоровье женщин и благополучии детей, недостижимых из-за вынужденной (обусловленной низким уровнем культуры) многодетности и исключительной бедности населения, которые он считает проблемами переходного периода. Таким образом, легализация медицинского аборта связывается Баткисом не с правом женщины на репродуктивный выбор (само представление об этом отсутствует), а с заботой советской власти о женщине в условиях, когда государство еще не может полностью возложить на нее обязанность материнства.

Исследователи обращают внимание на то, что, начиная с 1920-х годов, «в СССР было распространено ни на чем не основанное убеждение, что преодоление трудностей переходного периода... автоматически приведут к возвращению массовой многодетности» [Вишневский и др. 2016]. Так, Баткис прямо заявляет: «До тех пор пока государство не сможет гарантировать существование каждого рожденного ребенка, до тех пор оно не имеет никакого права возлагать на женщину никаких обязательств по рождению детей». Несмотря на это, с женщинами проводятся профилактические беседы, обсуждаются обстоятельства, из-за которых они решаются на аборт, ищутся и находятся возможности его предотвратить, причем, обдумывая свои обстоятельства и решение, женщина должна находиться в коллективе других женщин, чтобы чувствовать их поддержку.

Задача состоит в том, убежден Баткис, чтобы она сама осознанно и добровольно отказалась от аборта: «Очень часто женщина решается на аборт, не потому что у неё тяжёлое материальное положение, а из-за незнания своих прав, которые определяют ее роль матери, или бывает, что она не способна в данный момент пользоваться своими 
правами. В этих случаях для оказания помощи образовывались комиссии, в которые входили, в основном, женщины - работниць и крестьянки. Женщины, которые хотели прервать беременность, принимались ими дружески и товарищески, и всеми обсуждались обстоятельства, приводящие женщину к проведению аборта, и также все вместе искали и находили средства и пути для предотвращения абортов».

Обоснование принятия в 1920 г. закона о легализации медицинского аборта, которое приводит Баткис, свидетельствует об изначальной двойственности советского гендерного проекта: провозглашая равенство женщин и мужчин, советская власть решала «женский вопрос», оставаясь в рамках классических патриархатных представлений о «естественности» предназначения женщины. На этой основе возникла советская концепция «социального материнства», вменившая женщине обязанность воспитывать и заботиться в масштабах всего общества. «Социальным материнством» фактически исчерпывался публичный опыт советской женщины и представления о доступной ей общественно значимой роли [Здравомыслова 2012].

Так рождался «советский патриархат». В этом процессе активную роль играло советское законодательство, в том числе первый в мире закон о легализации медицинского аборта и меры по предотвращению абортов, с ним связанные.

По мере того, как советская гендерная политика все больше зависела от необходимости справляться с нарастающими проблемами и противоречиями, которые невозможно было разрешить революционными законами, государство усиливало контроль над женщинами, мобилизуя их на выполнение задач, поставленных властью. Фактически Баткис показывает, что модель женской эмансипации, созданная большевистской революцией, - «освобожденная трудящаяся женщина, проделавщая путь от непросвещённой бабы до грамотной гражданки», - не соответствует в полной мере задачам нового периода. Тем не менее он пытается сохранить революционный концепт «освобожденная женщина» - и конструирует формулировку, которая отражает переход от языка сексуальной революции к языку «советского патриархата»: «многовековое подавление и рабство женщины было устранено через установление более совершенных норм законодательства, принятых благодаря сильной воле и иелеустремленности советского правительства».

\section{СЕКСУАЛЬНАЯ РЕВОЛЮЦИЯ В РОССИИ: ПРОИГРАВШАЯ ИЛИ ОТЛОЖЕННАЯ?}

Баткис верил в реальность совершенного большевиками эмансипаторского переворота, который должен преобразить отношения женщин и мужчин, «освободив любовь от всех политических и экономических зависимостей». Он попытался соединить в единое целое революционные декларации о сексуальной свободе и «освобожденной женщине», революционные законы, изменившие правовую модель брака, и меры нарастающей властной опеки над личностью, приближавшие переход к сталинскому тоталитарному контролю. Однако написанная в начале 1920-ых годов брошюра, в которой Баткис стремился представить триумф сексуальной революции в России, скорее, предвосхитила 
вывод, сделанный в 1936 г. Троцким: «Взять старую семью штурмом не удалось. Не потому, что не хватило доброй воли. И не потому, что семья так прочно держалась в сердиах... К несчастью, общество оказалось слишком бедно и малокультурно. Планам и намерениям коммунистической партии не отвечали реальные ресурсы государства... Действительное освобождение женщины неосуществимо на фундаменте «обобщенной нуждыл.. Опыт скоро обнаружил эту суровую истину, которую Маркс формулировал за 80 лет до того» [Троцкий 1991: 80].

Вильгельм Райх недвусмысленно противопоставил первые годы советской власти, когда «коренному изменению экономических отношений сопутствовала революция в сексуальной жизни» [Райх 1997: 203], началу 1930-х годов, когда эта революция, названная Райхом «движением к свободе», окончательно отступила под натиском тоталитарных методов и репрессивных законов, принятых в период сталинского правления. Среди современных российских исследователей распространена точка зрения, что политика первых лет советской власти вся целиком является только логическим звеном в установлении, по выражению И.С. Кона, «командно-административных методов в регулировании сексуальности и сферы семейных отношений» [Кон 1997: 118; Тартаковская 2012; Aristarkhova 1995].

Размышляя над брошюрой Г.А. Баткиса, хотелось бы подчеркнуть другой вывод: революция в семейно-брачном законодательстве, действительно совершенная большевиками, не привела к настоящим изменениям сексуальной, гендерной и семейной культуры России. Более того, она продемонстрировала, что, несмотря на все усилия авторитарной власти, эти глубинные процессы не могут быть «учреждены» или «отменены» указами и законодательством. Однако было бы неверно считать сексуальную революцию в России «несостоявшейся» или проигравшей - скорее ее можно назвать отложенной.

Процесс, происходивший в годы становления советской власти - уникальный опыт соединения политической и сексуальной революций, осуществленный в крестьянской стране, где численность сколько-нибудь образованных людей составляла меньше трети населения. Это, во многом предопределило торможение процессов эмансипации, модернизации семьи и гендерной культуры, предпосылки которых были созданы благодаря новому либеральному подходу в семейно-брачном законодательстве. Вместе с тем значение этого подхода возрастало в России на протяжении всего XX века, по мере того, как трансформировался, уходя в прошлое, «советский патриархат».

М.С. Тольц убедительно показал, что либерализация семейно-брачного законодательства, которая происходила в СССР с конца 1960-х годов в период правления Брежнева, «для советского законодательства была во многом возвращением к нормам, привнесенным революцией и отвергнутым Сталиным» [Тольц 2013]. Ш. Курильски-Ожвэн обращает внимание на то, что связь с законодательным опытом 1920-х, прерванная в 1930е годы, ясно прослеживается в 1990-е, когда в 7-ю статью Конституции РФ было включено «революционное» положение о равной ценности материнства и отцовства [КурильскиОжвэн 1995: 166]. А в 2017 г. Правительством РФ принята Национальная стратегия 
действий в интересах женщин на 2017-2022 гг., в которой декларируются ценности женской эмансипации ${ }^{8}$, которые вряд ли можно «изъять» из российской культуры.

В то же время повседневность и, в широком смысле, социальная практика остаются постоянным источником новых ситуаций, противоречий и конфликтов, поэтому отношения, обусловленные гендером и сексуальностью, никогда не остаются теми же самыми и открываются возможности для их трансформации. Используя эти возможности, люди конструируют свои жизненные стратегии и проекты, создают общественные движения и участвуют в политических изменениях [Connell 1987].

Такое понимание стало развиваться в теориях гендера и сексуальности, отсылающих к опыту европейских и американских молодежных и женских движений 1960-х - 1970-х годов, в которых лежат истоки современной сексуальной революции. В ней можно усмотреть связь с большевистской, которую описывали Баткис и Райх, но революция второй половины XX века действительно изменила сознание и поведение людей. В результате ее гендерное равенство оказалось в центре интеллектуальных и общественных движений, были оспорены патриархатные представления о фемининности и маскулинности и произошли глубокие изменения в гендерной политике многих стран мира, которые невозможно насильственно повернуть вспять.

Эти процессы продолжают влиять на семью и демографическое поведение, сексуальность и гендерные нормы, индивидуальные и коллективные стратегии мужчин и женщин новых поколений.

\section{ЛИТЕРАТУРА}

Айвазова С.Г. (1998). Русские женщины в лабиринте равноправия (Очерки политической теории и истории). М.: РИК Русанова. 408 с.

Арендт Х.(2011). О революции. М.: Европа. 437 с.

Бердяев Н.А. (1924). Новое средневековье. Размышление о судьбе России. Берлин: Обелиск. 142 с.

Большая медицинская энциклопедия (1988) / Гл. ред. Б.В. Петровский. 3-е изд. М. : Советская энциклопедия.

Вишневский А.Г., В.И. Сакевич, Б.П. Денисов (2016). Запрет аборта: освежите вашу память // Демоскоп Weekly. 707-708. URL:

http://demoscope.ru/weekly/2016/0707/tema01.php (дата обращения: 23.12.2016).

Вишневский А.Г. (2010). Серп и рубль: Консервативная модернизация в СССР. М.: Изд. дом Высшей школы экономики. 432 с.

\footnotetext{
${ }^{8}$ «Национальная стратегия действий в интересах женщин на 2017 - 2022 годы» определяет основные направления государственной политики в отношении женщин и нацелена на реализацию принципа равных прав и свобод мужчины и женщины и создание равных возможностей для их реализации женщинами» [Национальная стратегия... 2017].
} 
Голод С.И. (2005). Что было пороками, стало нравами: лекции по социологии сексуальности. М.: Ладомир. 230 с.

Голосенко И.А., С.И. Голод (1998). Социологические исследования проституции в России: История и современное состояние вопроса. СПб.: Петрополис. 126 с.

Здравомыслова Е.А., А.А. Тёмкина (2004). Государственное конструирование гендера в советском обществе // Журнал исследований социальной политики. 1. 3-4: 299-321.

Здравомыслова Е.А. (2010). Гендерное гражданство и абортная культура // Демоскоп Weekly. 409-410. URL: http://demoscope.ru/weekly/2010/0409/analit01 .php (дата обращения: 23.12.2016).

Здравомыслова О.М. (2012). Российские женщины и эмансипация: незавершенный проект // Неприкосновенный запас. Дебаты о политике и культуре. 83 (3/2012): 42-51.

Карлсен Н. (2005). Григорий Абрамович Баткис (к 110-летию со дня рождения) // Демоскоп Weekly. URL: http://demoscope.ru/weekly/2005/0225/nauka03.php (дата обращения: 23.12.2016).

Кон И.С. (1997). Клубничка на березке. Сексуальная культура в России. М.: ОГИ. 464 с.

Кон И.С. (2010). Три в одном: сексуальная, гендерная и семейная революции // Международная конференция "Российский гендерный порядок: искусство, литература, массовая культура" (РФ, Санкт-Петербург, Санкт-Петербургский государственный университет, 19 ноября 2010 г.). URL: http://demoscope.ru/weekly/2010/0447/analit05.php (дата обращения: 23.12.2016).

Концепция государственной семейной политики Российской Федерации на период до 2025 года (2014). URL: https://rg.ru/2014/08/29/semya-site-dok.html (дата обращения: 14.10. 2016).

Курильски-Ожвэн Ш. (1995). Русская культурная модель и эволюция нормативного регулирования семьи // Общественные науки и современность. 5: 155 - 168 .

Ленин В.И. (1970). О значении воинствующего материализма // ПСС. 45. М.: Издательство политической литературы: 23-33.

Национальная стратегия... (2017). Национальная стратегия действий в интересах женщин на 2017 - 2022 годы. URL: http://government.ru/docs/26698/ (дата обращения: 18.02. 2017).

Пушкарева Н.Л. (2012). Гендерная система Советской России и судьбы россиянок // Новое литературное обозрение. 117. URL: http://www.nlobooks.ru/node/2613 (дата обращения: 14.10.2016).

Райх В. (1997). Сексуальная революция. М.: АСТ. 352 с.

Сакевич В.И., Б.П. Денисов, М. Ривкин-Фиш. (2016). Непоследовательная политика в области контроля рождаемости и динамика уровня абортов в России // Журнал исследований социальной политики. 14. 4: $461-475$.

Сорокин П.А (2006). Американская сексуальная революция. М.: Международный институт П. Сорокина - Н. Кондратьева. 192 с.

Сорокин П.А. (1922). Влияние войны на состав населения, его свойства и общественную организацию // Экономист. 1: 71 -88.

Социальная гигиена... (1984). Социальная гигиена и организация здравоохранения / Ред. А.Ф. Сергиенко, В.В. Ермков. М.: Медицина. 640 с. 
Тартаковская И.Н. (2012). Становление современной российской гендерной системы. URL: http://genderpage.ru/?p=744 (дата обращения: 14.10.2016).

Тольц М.С. (2013). Традиционалист Сталин, реакционер Хрущев и либерал Брежнев: отношение к проблемам семьи как зеркало истории СССР // Совершенно секретно. 8: $18-19$.

Троцкий Л.Д. (1991). Преданная революция. Что такое СССР и куда он идет? М.: НИИ культуры Министерства культуры РСФСР. 256 с.

Фуко М. (1982). Интервью: Секс, власть и политика идентичности. URL: http://syg.ma/@ nikita-archipov/mishiel-fuko-sieks-vlast-i-politika-idientichnosti (дата обращения: 14.10.2016).

Aristarkhova I. Women and government in bolshevik Russia (1995) // Labour Studies Working Papers. 4. University of Warwick. URL:

https://www.academia.edu/4923908/Women_and_Government_in_Bolshevik_Russia (дата обращения: 14.10.2016)

Batkis G. (1925). Die sexualrevolution in Russland. Berlin: Der Syndikalist Fritz Katen. 23 p.

Connell R.W. (1987). Gender and Power. Society, the person and sexual politics. Cambridge: Polity Press Ltd. 352 p.

Fitzpatrick S. (1978). Sex and revolution: an examination of literary and statistical data on the mores of Soviet students in the 1920s // Journal of modern history. 50: 252 - 278.

Giddens A. (1992). The Transformation of intimacy. Sexuality, love, and eroticism in modern societies. Cambridge: Polity Press. 216 p.

Kukhterin S. (2000). Fathers and patriarchs in communist and post-communist Russia // Gender, state and society in soviet and post-soviet Russia / Ashwin S., ed. London: Routledge: 71-89. 


\title{
HOW WAS BORN THE "SOVIET PATRIARCHY". GRIGORY BATKIS ABOUT THE SEXUAL REVOLUTION IN RUSSIA
}

\section{OLGA ZDRAVOMYSLOVA}

\begin{abstract}
The article analyzes the brochure "The Sexual Revolution in Russia" by Grigory Batkis, one of the founders of Russian social hygiene and sanitary statistics. This brochure, published in 1925 in Germany and never published in Russia, is an authentic document from the period 1917-1923 that is of paramount importance for understanding the Soviet gender project, as well as a new historical source supplementing existing ideas about the origins and circumstances of the emergence of the Soviet statist gender order, or the "Soviet patriarchy".
\end{abstract}
Batkis' concept of sexual revolution differs significantly from modern concepts. He defines the sexual revolution as a direct result and continuation of the October Revolution, aimed at destroying the "old Russian family and marital order" as socially unfair and historically doomed.

Batkis unites elements of three social revolutions that modern researchers differentiate: sexual, gender, and family. However, their driving force is not the progress of individualization and the expansion of the space of individual freedom, but the will of power expressed in the "legislation of the Russian communist revolution" (Batkis). In fact, for Batkis the sexual revolution coincides with the adoption of the first Bolshevik laws on family and marriage.

The article examines the similarities and differences in the interpretations of the sexual revolution in Russia by Grigory Batkis and Wilhelm Reich.

The sexual revolution in Russia did not bring about real changes in sexual and gender culture, but it would be wrong to consider it a failed movement; instead, it should be considered a postponed one.

Keywords: sexual revolution, Soviet patriarchy, Soviet gender project.

Olga M. ZdRAVOMYSLOVA (olgazdrav@gorby.ru), THE INTERNATIONAL FoundaTION FOR SOCIO-ECONOMIC AND Political STUdies, Russia.

DATE RECEIVED : OCTOBER 2017.

\section{REFERENCES}

Aivazova S.G. (1998). Russkie zhenshchiny v labirinte ravnopraviya (Ocherki politicheskoy teorii $\mathrm{i}$ istorii) [Russian women in the labyrinth of equality (Essays on political theory and history)]. Moscow: RIK Rusanova. 408 p.

Arendt H. (2011). O revolyutsi [On revolution]. Moscow: Evropa. 437 p. (Arendt H. (1963). New York: Viking. 343p.)

Aristarkhova I. Women and government in bolshevik Russia (1995) // Labour Studies Working Papers. 4. University of Warwick. URL:

https://www.academia.edu/4923908/Women_and_Government_in_Bolshevik_Russia (дата обращения: 14.10.2016)

Batkis G. (1925). Die sexualrevolution in Russland. Berlin: Der Syndikalist Fritz Katen. 23 p. 
Berdyaev N.A. (1924). Novoe srednevekov'e. Razmyshlenie o sud'be Rossiii [New middle ages. Reflection on the fate of Russia]. Berlin: The obelisk. 142 p.

Connell R.W. (1987). Gender and. Power. Society, the person and sexual politics. Cambridge: Polity Press Ltd. 352 p.

Fitzpatrick S. (1978). Sex and revolution: an examination of literary and statistical data on the mores of Soviet students in the 1920s // Journal of modern history. 50: 252-278.

Foucault M. (1982). Interv'yu: Seks, vlast' i politika identichnosti [An Interview: Sex, power and the politics of identity] URL: http://syg.ma/@ nikita-archipov/mishiel-fuko-sieks-vlast-ipolitika-idientichnosti (Foucault M. (1982). An Interview: Sex, power and the politics of identity, conducted by Bob Gallagher and Alexander Wilson. URL:

https://schwarzemilch.files.wordpress.com/2009/02/foucault-sex-power-and-the-politics-ofidentity.pdf (accessed 14.10.2016)).

Giddens A. (1992). The Transformation of intimacy. Sexuality, love, and eroticism in modern societies. Cambridge: Polity Press. 216 p.

Golod S.I. (2005). Chto bylo porokami, stalo nravami: lektsii po sotsiologii seksual'nosti [What was vices, became morals: Lectures on the sociology of sexuality]. Moscow: Ladomir. $230 \mathrm{p}$.

Golosenko I.A., S.I. Golod (1998). Sotsiologicheskie issledovaniya prostitutsii v Rossii: istoriya i sovremennoe sostoyanie voprosa [Sociological studies of prostitution in Russia: history and the current state of the issue]. Sankt-Peterburg: Petropolis. $126 \mathrm{p}$.

Karlsen N. (2005). Grigoriy Abramovich Batkis (k 110-letiyu so dnya rozhdeniya) [Grigory Abramovich Batkis (to the 110th anniversary of his birth day)] // Demoscop Weekly [Demoscope Weekly]. URL: http://demoscope.ru/weekly/2005/0225/nauka03.php (accessed : 23.12.2016).

Kon I.S. (1997). Klubnichka na berezke. Seksual'naya kul'tura v Rossii [Strawberry on the birch. Sexual culture in Russia]. Moscow: OGI. 464 p.

Kon I.S. (2010). Tri v odnom: seksual'naya, gendernaya i semeynaya revolyutsii [Three in one: sexual, gender and family revolutions] // Mezhdunarodnaya konferentsiya "Rossiyskiy gendernyy poryadok: iskusstvo, literatura, massovaya kul'tura" (RF, Sankt-Peterburg, SanktPeterburgskiy gosudarstvennyy universitet, 19 noyabrya 2010 g.) [International conference "Russian gender order: art, literature, mass culture" (RF, Sankt-Pererburg, St. Petersburg State University, 19 November, 2010)]. URL: http://demoscope.ru/weekly/2010/0447/analit05.php (accessed : 23.12.2016).

Kontseptsiya gosudarstvennoy semeynoy politiki Rossiyskoy Federatsii na period do 2025 goda [The concept of the state family policy of the Russian Federation for the period until 2025]. URL: https://rg.ru/2014/08/29/semya-site-dok.html (accessed 14.10. 2016).

Kukhterin S. (2000). Fathers and patriarchs in communist and post-communist Russia // Gender, state and society in soviet and post-soviet Russia / Ashwin S., ed. London: Routledge: 71-89.

Kurilsky-Ozhven Sh. (1995). Russkaya kul'turnaya model' i evolyutsiya normativnogo regulirovaniya sem'i [Russian cultural model and the evolution of regulatory family regulation] // Obshchestvennye nauki i sovremennost' [Social sciences]. 5: $155-168$.

Lenin V.I. (1970). O znachenii voinstvuyushchego materializma [On the significance of militant materialism] // Works. 45. Moscow: Izdatel'stvo politicheskoy literatury: 23-33.

Natsional'naya strategiya... [National Strategy...] (2017). Natsional'naya strategiya deǐstvĭ̌ v interesakh zhenshchin na 2017 - 2022 gody [National Strategy of action in the interests of women 2017-2022]. URL: http://government.ru/docs/26698/ (accessed 18.02. 2017). 
Pushkareva N.L. (2012). Gendernaya sistema Sovetskoy Rossii i sud'by rossiyanok [The gender system of Soviet Russia and the fate of Russian women] // Novoe literaturnoe obozrenie [New literary observer]. 117. URL: http://www.nlobooks.ru/node/2613 (accessed: 14.10.2016).

Reich V. (1997). Seksual'naya revolyutsiya [The Sexual Revolution]. Moscow: AST. 352 p. (Reich V. (1974). The Sexual Revolution. Toward a self regulating character structure. NY: Farrar, Straus and Giroux. 283 p.).

Sakevich V.I., B.P. Denisov, M. Rivkin-Fish (2016). Neposledovatel'naya politika v oblasti kontrolya rozhdaemosti i dinamika urovnya abortov v Rossii [Inconsistent policies in the field of birth control and the dynamics of abortion in Russia] // Zhurnal issledovaniy sotsial'noy politiki [Journal of social policy studies]. 14. 4: 461-475.

Sorokin P.A. (1922). Vliyanie voyny na sostav naseleniya, ego svoystva i obshchestvennuyu organizatsiyu [The influence of war on the composition of the population, its properties and social organization] // Ekonomist [The economist]. 1: $71-88$.

Sorokin P.A. (2006). Amerikanskaya seksual'naya revolyutsiya [The American sex revolution]. Moscow : Mezhdunadodny institut P.Sorokina-N.Kondrat'eva. 192 s. (Sorokin P.A. (1956). The American sex revolution. An Extending horizons book. Boston: P. Sargent. 186 p.).

Sotsial'naya gigiena... [Social hygiene...] (1984). Sotsial'naya gigiena i organizatsiya zdravookhraneniya [Social hygiene and the organization of public health service] / A.F. Sergienko, V.V. Ermkov, eds. Moscow: Meditsina. 640 p.

Tartakovskaya I.N. (2012). Stanovlenie sovremennoy rossiyskoy gendernoy sistemy [Formation of the modern Russian gender system]. URL: http://genderpage.ru/?p=744 (accessed 14.10.2016).

The great medical encyclopedia (1988) / B.V. Petrovsky, ed. 3-rd edition. Moscow: Sovetskaya entsiklopediya.

Tolts M.S. (2013). Traditsionalist Stalin, reaktsioner Khrushchev i liberal Brezhnev: otnoshenie k problemam sem'i kak zerkalo istorii SSSR [Traditionalist Stalin, reactionary Khrushchev and liberal Brezhnev: Attitude to family problems as a mirror of Soviet history] // Sovershenno sekretno [Top secret]. 8: 18-19.

Trotsky L. (1991). Predannaya revolyutsiya. Chto takoe SSSR i kuda on idet? [The Revolution betrayed: What is the Soviet Union and where is it going?]. Moscow: NII kul'tury Ministerstva kul'tury RSFSR. 256 p. (Trotsky L. (1937). The Revolution betrayed: What is the Soviet Union and where is it going? New York: Doubleday, Doran and Co. 308 p.).

Vishnevsky A.G. (2010). Serp i rubl': Konservativnaya modernizatsiya v SSSR [Sickle and Ruble: Conservative Modernization in the USSR]. Moscow: Izd. dom Vysshey shkoly ekonomiki. 432 p.

Vishnevsky A.G., V.I. Sakevich, B.P Denisov (2016). Zapret aborta: osvezhite vashu pamyat' [The prohibition of abortion: refresh your memory] // Demoscop Weekly [Demoscope Weekly]. 707-708. URL: http://demoscope.ru/weekly/2016/0707/tema01.php (accessed 23.12.2016).

Zdravomyslova E.A, A.A. Tyomkina (2004). Gosudarstvennoe konstruirovanie gendera v sovetskom obshchestve [State construction of gender in Soviet society] // Zhurnal issledovaniy sotsial'noy politiki [Journal of social policy studies]. 1. 3-4: 299-321. 
Zdravomyslova E.A. (2010). Gendernoe grazhdanstvo i abortnaya kul'tura [Gender citizenship and abortion culture] // Demoscop Weekly [Demoscope Weekly]. 409-410. URL: http://demoscope.ru/weekly/2010/0409/analit01.php (accessed 23.12.2016).

Zdravomyslova O.M. (2012). Rossiyskie zhenshchiny i emansipatsiya: nezavershennyy proekt [Russian women and emancipation: incomplete project] // Neprikosnovennyy zapas. Debaty o politike i kul'ture [Neprikosnovennyi zapas. Debate about politics and culture]. 83 (3/2012): 42-51. 